\title{
IMPLEMENTATION OF CURRICULUM 2013 FOR PHYSICAL EDUCATION, SPORT AND HEALT OF JUNIOR HIGHSCHOOL IN SAMARINDA
}

\author{
Muhammad Sukron Fauzi ${ }^{1}$ \\ Program Study for Physical Education, Health and Recreation. FKIP Mulawarman University, \\ Samarinda City ${ }^{1}$ \\ Email: Sukronfauzi950@yahoo.com
}

\begin{abstract}
This study aims to determining the Implementation of Curriculum 2013 in the scope of content standard, process standard, and assessment standard for Physical Education, Sport, and Health of junior high school.

This study was an evaluation research based on mix method of deskriptif quantitative approach. The evaluation model was responsive that had an objective to find out the responses of teachers about the implementation of curriculum 2013. This study was taken place in Junior High School. The total of the population was 81 School and the sample used in this study were 20 school based on the proportionate stratified random sampling technique. The data collection instrument were questionnaires for teachers physical education sport and health.

The findings showed. The implementation of Curriculum 2013 in the scope of content standard was appropriate with the guidance of Curriculum 2013 with the percentage of respondent's response was 82,4\%, The implementation of Curriculum 2013 in the scope of process standard was appropriate with the rules of Curriculum 2013 with the percentage of respondents response was $82,8 \%$, The implementation of Curriculum 2013 in the scope of assessment standard was appropriate with the guidance of Curriculum 2013 with the percentage of respondents response was $80,4 \%$.

Conclusions are the implementation of the 2013 curriculum including content standards, process standards, and assessment standards for junior high schools in the city of Samarinda, which have run according to the format, guidelines and policies of the government regarding the implementation of the 2013 curriculum.
\end{abstract}

Keywords: Implementation, Curriculum 2013, Physical Education Sport and Health

\section{INTRODUCTION}

Implementation curriculum is a very decisive component in an educational system, therefore the curriculum is a tool to achieve the education system, therefore the curriculum is a tool to achieve the goals of education and as well as a guide in the implementation of teaching on all types and levels of education (Azis, 2018). Success and failure of a school depends on the curriculum that is used. The curriculum can be seen as a concrete plan of the application of an educational theory (sukmadinata, 2013). Curriculum 2013 is a new curriculum that began to be implemented in the 2013/2014 Academic Year. This curriculum is the development of an 
existing curriculum, both competency-based curriculum was pioneered in 2004 and the education unit level curriculum in 2006. However, the point of emphasis in the 2013 curriculum is that there has been an increase in and the soft skills and hard skills that cover aspects of attitude, skills and knowledge competencies (Fadlillah, 2014). Thus, the position of which was originally derived from the competence of the subjects developed turned into subjects of competence.

The 2013 curriculum is a new curriculum that began to be implemented in 2013/2014. This curriculum is the development of a curriculum that has been there before, both competency based curriculum that has been initiated in 2004 and the Curriculum Education Unit in 2006. It's just the pressure point on the curriculum in 2013 this is an increase and balanced soft skills and hard skills which includes aspects of competency in attitude, skills, and knowledge (Fadlillah, 2014). Thus, the position of which was originally derived from the competence of the subjects developed turned into subjects of competence.

The curriculum from time to time always changes and develops in a better direction in accordance with the demands of the times and advances in science and technology. The changes are an undeniable necessity; it also penetrated the education world as an answer to the phenomenon of a dynamics society living. Changes are needed to prepare young generation in facing great Indonesia that needs qualified and ready human resources to compete in the global market (Hidayati, 1970). The curriculum is structured with attention to the times that do not lose their identity and personality as an Indonesian nation by emphasizing character education. As expressed by (Hamalik, 2013) Curriculum development is a curriculum planning process to produce a broad and specific curriculum plan. Changes in curriculum last was in 2013 called Curriculum 2013, which is the development of the curriculum approach to scientific for education units, middle and high school as well as a thematic approach to SD with the scoring system authentic that emphasizes not only the result of the learner but also a judgment on the process.

(Retnaningsih, 2013) in the journal stated the actual issues related to the new curriculum in 2013 which are the subject matter issue and readiness of human resources (teachers). From this knowledge of teachers on curriculum implementation in 2013 needs to be examined so that the application includes content standards, standardized processes and standard of assessment could have been better. Because this 2013 curriculum in its implementation is still lacking. (Alawiyah, 2014) explains At the beginning of the launch of the policy and the start of implementation of this curriculum has been for controversy. Preparation of the 2013 Curriculum is considered not to refer to the results of a mature study based on the results of the KTSP 
evaluation, and less attention to the readiness of teacher education and human resources (HR) units.

Curriculum Evaluation is a series of systematic actions in gathering information, giving consideration and decisions regarding the value and meaning of the curriculum ((Kementrian Pendidikan dan Kebudayaan Republik Indonesia), 2013). Considerations and decisions regarding values regarding ideas, design, implementation, and results of the curriculum. Considerations and decisions about the meaning regarding the impact of the curriculum on society. As stated by Hidayat (2013: 2) The curriculum as an instrumental input in achieving national education goals is developed dynamically in accordance with the demands and changes that occur in society. Evaluation focuses on four dimensions, namely ideas, documents, implementation, and results. Evaluation of two dimensions namely ideas and designs have been carried out during the development process while for evaluation of the implementation of the curriculum is intended to examine the designs made by the education unit, learning implementation plans (RPP), and learning activities. This study was conducted to determine the extent to which the curriculum implementation process is able to achieve the expected.

Preliminary study of the field by taking the initial data to 16 junior high schools / private in Samarinda by providing petanyaan regarding the implementation of Curriculum 2013 for each 1 teacher of physical education, sports and health in every 16 junior who is the subject of the beginning of the study, which scattered in 5 districts of Samarinda City. Based on survey results, out of 16 teachers PJOK, 75\% stated that the teaching curriculum in 2013 in physical education, sports and health teachers are still difficulties in its application as a standard process, learning by saitifik approach. PJOK of 16 teachers, $88 \%$ expressed a lot of obstacles in the implementation of Curriculum 2013 in terms of facilities and infrastructure of learning and learning media are not adequate. Of the 16 PJOK teachers, $81 \%$ said they did not understand the authentic assessment of the 2013 curriculum, there were too many assessment rubrics that had to be filled and too many aspects were assessed in attitude assessment. This is part of the results of the research (Suherman, 2014) The results showed that the implementation of the curriculum in 2013 has not been in accordance with the demands of school teachers even seem difficult, therefore, to improve the quality of the learning process is recommended for teachers to understand more about the implementation of the curriculum in 2013 and the principals and related parties in order to complete the infrastructure for learning improving the quality of processes and maximum learning results. 


\section{METHOD}

This research is evaluative research. The approach used in this study is a quantitative approach with descriptive presentation of research results in the form of numbers through statistical analysis. Quantitative descriptive approach in this study is used with consideration in order to get a comprehensive understanding and interpretation of the 2013 curriculum implementation in junior high schools in Samarinda City, so that a comprehensive evaluation results are obtained. With the purposes of research, evaluation research use model is responsive, that is the approach taken of several measurement precision in order to improve the usefulness of the findings to people in and around the program.

The population in this study is 81 junior high schools in Samarinda City. While the sample in this study is public and private junior high schools that are still implementing the 2013 curriculum and that do not implement the 2013 curriculum which amounts to 20 public and private junior high schools. Proportionate sampling using stratified random sampling technique, the technique is used when the population has members / elements that are not homogeneous and stratified proportional.

Data collection techniques used was questionnaires. Questionnaires were shown to PJOK teachers in state and private junior high schools in Samarinda City. This study tried to find answers from developing issues related to the learning exercise and health physical education curriculum in 2013, so that with the approach of quantitative descriptive explanation of the results of research supported by the analysis of the data percentage (Sugiyono, 2010).

\section{FINDINGS AND DISCUSSION}

Curriculum 2013 for all units of primary and secondary education, is one of the central and strategic step within the framework of strengthening the character of the Indonesian nation toward civil. The curriculum in 2013 developed a comprehensive, integrated, dynamic, accommodating, and adaptable to the challenges of the future. Curriculum 2013 is designed based on the culture and character of the nation, based civilization, and based on competence

\section{1) Standard Aspects of 2013 Curriculum Contents}

Analysis PJOK teacher feedback on the content of the standard curriculum in 2013 at the Junior High School level in Samarinda conducted on 20 teachers PJOK measured 42-point declaration consists of sub-indicators: learning tools and curriculum structure. More detailed results of the descriptive analysis of data content standards can be seen in the table and illustrated below: 
Table 1: Results of Descriptive Calculation of Percentage of Standards in the 2013 Curriculum. Figure 1

\begin{tabular}{cccccc}
\hline No & Interval & Criteria & Frequency & Percentage & Mean \\
\hline 1 & $81,3 \%-100 \%$ & Very Suitable & 10 & $50 \%$ & $82,4 \%$ \\
2 & $62,5 \%-81,3 \%$ & Suitable & 10 & $50 \%$ & \\
3 & $43,8 \%-62,5 \%$ & Unsuitable & 0 & $0 \%$ & \\
4 & $<25 \%-43,8 \%$ & Very Unsuitable & 0 & $0 \%$ & \\
\hline & Total & & 20 & $100 \%$ & Suitable \\
\hline
\end{tabular}

The Result of the Implementation Of Content Standard in 2013 Curriculum. On Picture 1

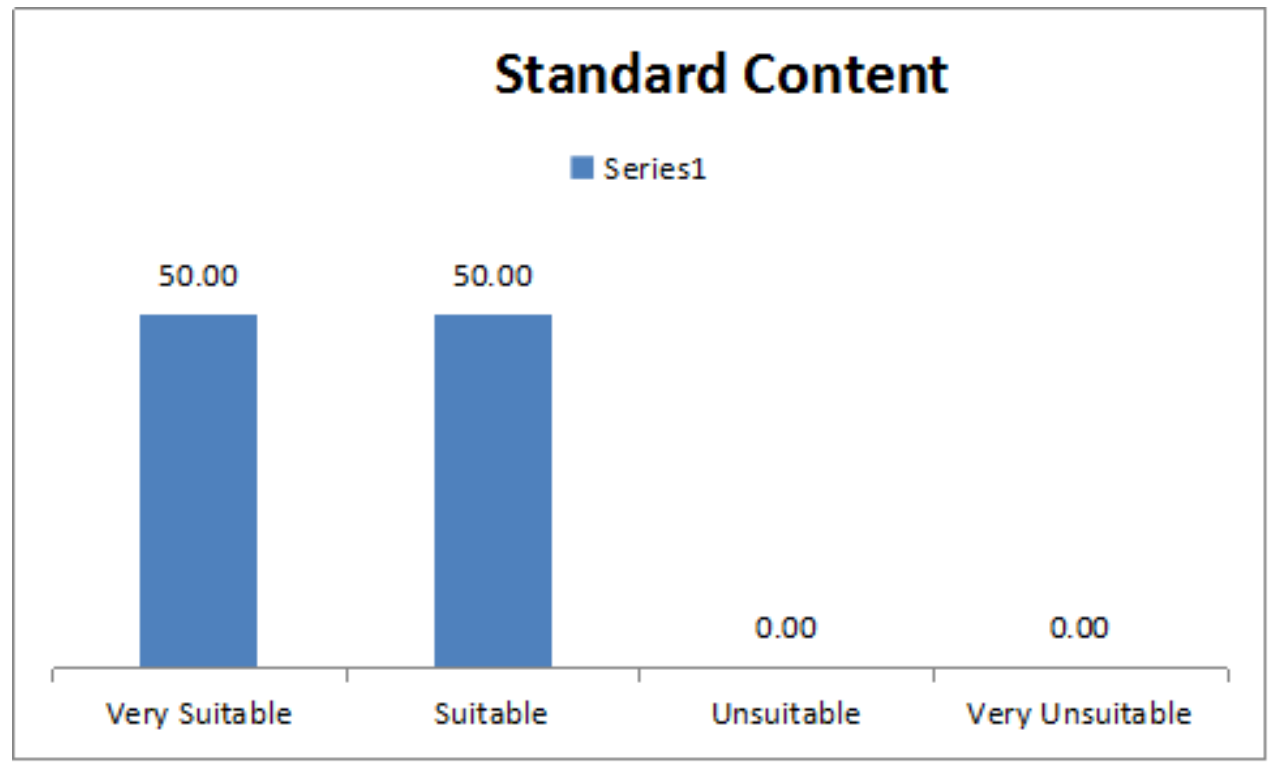

Figure 1. Diagram Stem Curriculum Content Standards in 2013

Table 1 and Figure 1 above, obtained a description that 10 teachers PJOK or equal to $50 \%$ to provide feedback on content standards have indicators of learning tools and learning structure in the implementation of Curriculum 2013 in subjects PJOK SMP public and private in Samarinda stated very appropriate, as many as 10 teachers together with $50 \%$ PJOK provide appropriate responses, no teachers PJOK included in the criteria that states are not appropriate and it is not appropriate. This gives an illustration that from this study PJOK teachers in public and private junior high schools in Samarinda City are in full accordance with the 2013 curriculum format and guidelines related to the content standards or the making of learning tools and the curriculum structure is in accordance with what is stipulated in the 2013 Curriculum. , relevance, efficiency and feasibility in PJOK learning in public and private junior Samarinda with an average of $82.4 \%$. 
The percentage analysis obtained results that most respondents stated that the implementation of the 2013 curriculum in terms of the standard content expressed in accordance with the effectiveness, relevance, efficiency and feasibility of Physical, Sports and Health lessons (PJOK) in public and private junior high schools in the city of Samarinda. Where as much as $82.4 \%$ of respondents PJOK teachers of public and private junior high school in Samarinda stated very appropriate. The results of this study are supported by the results of questionnaires given to students in which the enforcement of the curriculum in 2013 where the results of teacher PJOK deliver the subject matter PJOK well and easily understood by learners, teachers PJOK could motivate learners in the learning process, teachers PJOK deliver the PJOK subject matter skillfully and easy to understand as well as teachers use instructional media PJOK to provide an understanding of the material to learners.

But in its implementation there are still difficulties and obstacles faced by PJOK teachers in making learning tools and curriculum structure. The difficulty in making learning devices, because there are differences in the previous curriculum in KTSP 2006, each subject stands alone and has its own basic competencies, while 2013 curriculum is related to each other and has basic competencies that are tied to the core competencies of each class. There is also a discrepancy between basic competencies with $\mathrm{KD}$ sounds and indicators, so that teachers find it difficult to develop learning tools. the results of the student questionnaire indicate that the learning device is not yet ready to be applied (Wibawa \& Kartowagiran, 2014).

\section{2) Aspect of Process Standard 2013}

The process standard is a criterion regarding the implementation of learning in an education unit to achieve the graduates' competency standards. Standards developed process refers to a competency standards and content standards that have been set. The results of descriptive analysis on the process standard variable data can be seen in the following table:

Tabel 2. Result Calculation Descriptive Percentage of Process Standard on 2013 Curriculum Figure 2

\begin{tabular}{cccccc}
\hline No & Interval & Criteria & Frequency & Percentage & Mean \\
\hline 1 & $81,3 \%-100 \%$ & Very Suitable & 12 & $60 \%$ & \\
2 & $62,5 \%-81,3 \%$ & Suitable & 8 & $40 \%$ & $82,8 \%$ \\
3 & $43,8 \%-62,5 \%$ & Unsuitable & 0 & $0 \%$ & \\
4 & $<25 \%-43,8 \%$ & Very Unsuitable & 0 & $0 \%$ & \\
\hline \multicolumn{2}{c}{ Total } & & 20 & $100 \%$ & Very \\
& & & & Suitable \\
\hline
\end{tabular}


Display the results of the implementation of standards in the process of Curriculum 2013 in Figure

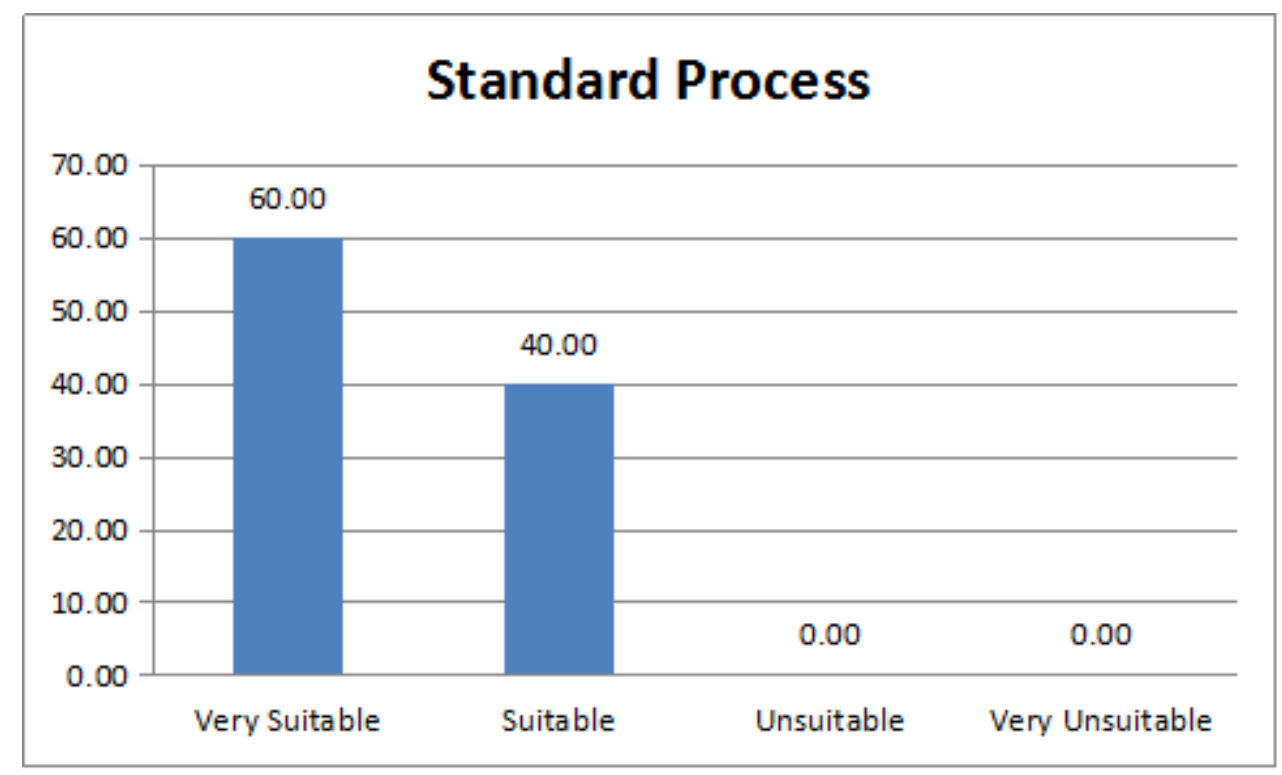

Figure 2. Stem Diagram of 2013 Curriculum Process Standards

Table 2 and Figure 2 above, 82.8\% of the PJOK teacher responses stated that the standard process in the implementation of the 2013 Curriculum used in public and private junior high schools in Kota Samarinda most of the PJOK teachers stated it was very appropriate, namely at $81.3 \%$ intervals - $100 \%$, as much as $60 \%$ of the PJOK teacher's responses are very suitable, as many as $40 \%$ of the PJOK teacher's responses are appropriate, there are no PJOK teachers included in the criteria that are inappropriate and very inappropriate. This gives an illustration that from this study the response of PJOK teachers in state and private junior high schools in Samarinda City is very in accordance with the format and guidelines of the 2013 curriculum in the application of the standard process scope.

In the process standard indicator analysis that examines the learning process states that in the process of implementing the 2013 curriculum in PJOK learning in public and private junior high schools is very suitable between what is contained in the 2013 curriculum implementation guidelines based on process standards with what has been implemented by the teacher in the PJOK learning process in public and private junior high schools in Kota Samarinda using the 2013 curriculum with an average percentage of $82.8 \%$. The data is supported by the analysis of student data that researchers did. Based on the results of the student questionnaire analysis of the learning process Physical education, sports and health in public and private junior high schools in Samarinda City get an average percentage of $93.5 \%$ stating that in the learning process physical, sports and health education, teachers choose learning methods according to the learning 
method contained in the 2013 curriculum is one of the problems based learning. In addition, the teacher approaches learning using the scientific approach, namely students are first given the opportunity to observe the learning material presented by the teacher, giving students the opportunity to ask questions about the material presented, giving students the opportunity for students to try and reason what is conveyed and explained by teacher so students can communicate the material taught or delivered by the teacher related to learning physical education, sports and health.

But in practice teachers are still experiencing difficulties and obstacles in the learning process with scientific approach. The process of learning the curriculum in 2013, teachers did not immediately explain the subject matter to the students but provoke students to explore a way to observe and students were told to read first ingredient material learned, obstacles when the learning process is, lack of awareness and interest of the students to read the implications and less active in the learning process. Students are still less enthusiastic about learning with the scientific method. As well as difficulties in the implementation of the curriculum in 2013, is at the attitude assessment, which must vote by week in week out, even had to pay attention to the attitude each day, thus making the teacher ran out of time for the next KBM necessarily have to exist such judgments. Although the government has made various preparations to support the implementation of Curriculum 2013 in order to run smoothly, but in the middle pejalanan still found a variety of problems, especially for teachers, especially in the domain of the process (Alawiyah, 2013).

\section{3) Aspects of Curriculum Assessment Standard 2013}

Curriculum assessment standards should include aspects of knowledge, skills, and attitudes intact and proportionate, in accordance with a predetermined core competence. Educational assessment standards are criteria regarding mechanisms, procedures and instruments for evaluating learning outcomes. Assessment of learning outcomes by educational units carried out to determine the success rate of learners and the achievement of value for all eyes lesson in SKL Curriculum 2013 votes over the assessment process or the authentic assessment where the assessment is not based on the final results alone but rather look at the process. The results of descriptive analysis on process standard data can be seen in the following table: 
Table 3. Calculation Results Descriptive Percentage of Standard Assessment in Curriculum 2013

\begin{tabular}{cccccc}
\hline No & Interval & Criteria & Frequency & Percentage & Mean \\
\hline 1 & $81,3 \%-100 \%$ & Very Suitable & 8 & $40 \%$ & \\
2 & $62,5 \%-81,3 \%$ & Suitable & 12 & $60 \%$ & $80,4 \%$ \\
3 & $43,8 \%-62,5 \%$ & Unsuitable & 0 & $0 \%$ & \\
4 & $<25 \%-43,8 \%$ & Very Unsuitable & 0 & $0 \%$ & \\
\hline & Total & & 20 & $100 \%$ & Suitable \\
\hline
\end{tabular}

Display the results of the application of the assessment standard on 2013 Curriculum in Figure

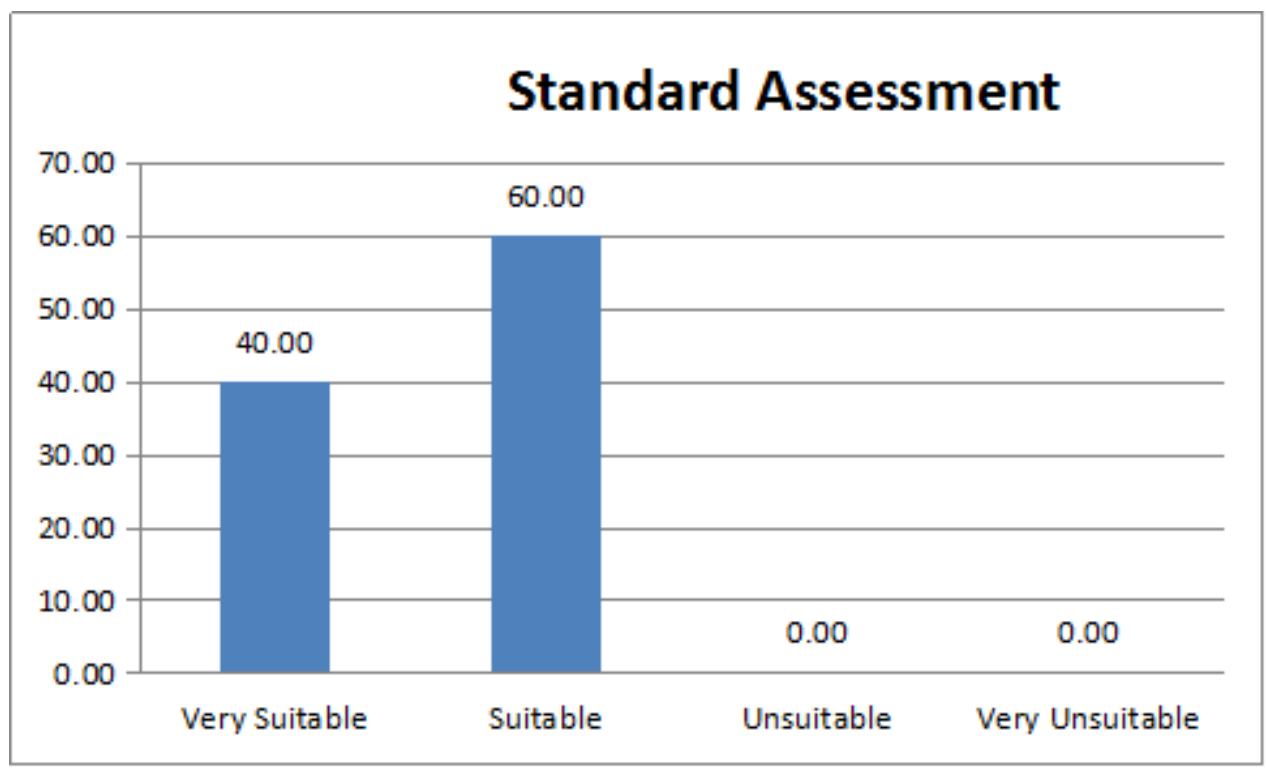

Figure 3 The 2013 Curriculum Assessment Standard Bar Chart

Table 3 and Figure 3 above, as many as $80.4 \%$ of the PJOK teacher responses stated that the assessment standards in the implementation of the 2013 Curriculum used in public and private junior high schools throughout Samarinda City most PJOK teachers stated that it was appropriate, namely at an interval of $62.5 \%-81.3 \%$ as many as $40 \%$ of PJOK teacher responses are very appropriate, as many as $60 \%$ of the PJOK teacher's responses are appropriate, no PJOK teacher is included in the criteria of inappropriate and very inappropriate. This gives that from this study the response of PJOK teachers in public and private junior high schools in Samarinda City is in accordance with the 2013 curriculum format in the application of assessment standards.

To evaluate how the implementation of the 2013 curriculum is related to assessment standards. The results of the standard assessment study conducted on 20 teachers of physical education, sports and health (PJOK) in junior high schools in Samarinda City showed that 80.4\% 
of respondents stated that the assessment standards in the 2013 curriculum were in accordance with the format and guidelines on physical education learning, sports and health (PJOK). This gives that the assessment carried out in the 2013 curriculum is not in the final result but in the process evaluation. in the evaluation of learning that uses scientific (scientific) approach emphasizes more on aspects of the process and effort of character building such as the ability to observe, ask, reason, process, try, conclude, present and communicate in the form of group and individual learning. Through the assessment of an educator or teacher will get information about the abilities of students and the achievement of the learning objectives that have been carried out (Widodo, 2014).

There are also obstacles and difficulties in the authentic assessment felt by PJOK teachers in their application. Constraints in evaluating Authentic in the 2013 curriculum can be concluded that the assessment of attitudes is the first and the foremost, followed by a skill and knowledge assessor, reversed with the 2006 curriculum that prioritizes cognitive. Many things that make the teacher experience obstacles are aspects of attitude assessment that have several elements, for example, the value of discipline, cooperation and respect for the opinions of others. In addition, in terms of skills as well, teachers must conduct observation observations and activity portfolios and aspects of knowledge assessment is done by understanding, understanding and being able to present, there are percentages and assessment of tasks. This assessment will result in an engineering attitude assessment, good students and bad students that are the benchmark for value differences, while others are of general standard and too many assessment rubrics that must be filled. It takes a very long time so the learning process is not optimal. as well as the lack of socialization to the curriculum in 2013, so the teachers are still having difficulties, in

implementing it, especially in the point of evaluation required in the curriculum teachers must give students an objective assessment, accountability, and informative.

\section{CONCLUSIONS}

Implementation of Curriculum 2013 in the content standards, standardized processes and standard of assessment on the subjects of PJOK junior high school in Samarinda has been implemented according to the reference to the format and curriculum guidelines set by the government. But there are obstacles, namely the aspects of availability and infrastructure conditions for the learning process is not adequate, and the lack of ability of the teacher or human resources (HR) teachers in making and applying the learning model in the implementation of Curriculum 2013. 


\section{REFERENCES}

Alawiyah, F. (2013). Dampak Implementasi Kurikulum 2013 Terhadap Guru. Info Singkat Kesejahteraan Sosial (P3DI) Setjen DPR RI, V(19), 9-12.

Alawiyah, F. (2014). Kesiapan Guru Dalam Implementasi Kurikulum 2013. Info Singkat Kesejahteraan Sosial - Pusat Pengkajian, Pengolahan Data, Dan Informasi (P3DI), VI(15), 9-12. Retrieved from www.dpr.go.id

Azis, R. (2018). Implementasi Pengembangan Kurikulum. Inspiratif Pendidikan, 7(1), 44. https://doi.org/10.24252/ip.v7i1.4932

Fadlillah, M. (2014). Implementasi Kurikulum 2013 Dalam Pembelajaran SD/MI, SMP/MTS, \& SMA/MA. Yogyakarta: Ar-Ruzz Media

Hamalik, Oemar. (2013). Dasar-Dasar Pengembangan Kurikulum. Bandung: PT Remaja Rosdakarya

Hidayat, Sholeh.(2013). Perkembangan Kurikulum Baru. Bandung: PT Remaja Rosdakarya.

Hidayati, L. (1970). Kurikulum 2013 dan Arah Baru Pendidikan Agama Islam. Insania: Jurnal Pemikiran Alternatif Kependidikan, 19(1), 60-86. https://doi.org/10.24090/insania.v19i1.464

(Kementrian Pendidikan dan Kebudayaan Republik Indonesia). (2013). Implementasi Kurikulum. Permendikbud, 81(A), 1-9. https://doi.org/10.1017/CBO9781107415324.004

Retnaningsih, H. (2013). Masalah Kurikulum Baru Tahun 2013. IV(24).

Sukmadinata, Syaodiah, Nana. (2013). Pengembangan Kurikulum Teori Dan Praktek. Bandung: PT Remaja Rosdakarya.

Suherman, A. (2014). Implementasi Kurikulum Baru Tahun 2013 Mata Pelajaran Pendidikan Jasmani (Studi Deskriptif Kualitatif pada SDN Cilengkrang). Mimbar Sekolah Dasar, 1(1). https://doi.org/10.17509/mimbar-sd.v1i1.866

Sugiyono. (2010). Metode Penelitian Pendidikan (Pendekatan Kuantitatif, Kualitatif, dan R\&D). Bandung: CV Alfabeta

Wibawa, E. A., \& Kartowagiran, B. (2014). Kesiapan Perangkat Pembelajaran Pengantar Akuntansi Dalam Rangka Implementasi Kurikulum 2013. Jurnal Evaluasi Pendidikan Pendahuluan, 2(2), 123-134.

Widodo, P. J. (2014). - Seminar Nasional Evaluasi Pendidikan Tahun 2014 —. Jurnal Indonesia, (2004), 121-128. 